\title{
Interregional Migration: Who Decides to Move?
}

\author{
Diana Castorina ${ }^{1}$ and Riccardo Welters ${ }^{2}$
}

\begin{abstract}
The functionality of a region depends on its people. Yet for some regions within Australia, attracting and retaining varied skilled people continues to be a challenge. What influences people to want to stay, move away from or move into a region? Before we can answer this question, we firstly need to understand 'who' is making this decision. Much of past research assumes the decision is made at the individual head of household level or must assume the decision is made at the individual as opposed to the household level as a result of data availability. This paper highlights the limitations of making such an assumption and offers an alternative method transforming secondary microdata to reflect the collective household unit as the decision making unit. We find that our migration models are statistically robust with results consistent with conventional studies that show smaller, younger households are more mobile. Most importantly, however, we find evidence that our proxies which represent characteristics of the collective unit, termed "Decision Making Unit", are also statistically significant. Thus, justifying the need for migration models to reflect the collective unit and not just the individual, should we seek to better understand motives.
\end{abstract}

JEL classification numbers: J61, R23, R58

Keywords: interregional migration, migration, decision-making, households, regions

\section{Introduction}

Despite the fact that it has been widely acknowledged for decades that households, rather than individuals are the appropriate unit of analysis when considering migration decisions (Chi \& Voss, 2005; Mincer, 1978; Smith, 2011) much analysis of migration has been done using individuals as the unit of analysis particularly so when secondary data has been used (Graves \& Linneman, 1979). Some studies have used 'the household' as the unit of analysis, but when measuring for example education, these studies typically consider the education level of the 'head of the household', thus failing to capture the education level of other members of the household, which are likely to influence the migration decision. Given the social changes that have occurred over the last five decades or so, such an approach may no longer be valid; particularly in countries such as Australia where females often make a substantial contribution to family income (Gorman-Murray et al., 2010; Waitt \& Gorman-Murray, 2011).

Contemporary human capital models of migration treat the decision to migrate (defined below) as an investment: people are believed to consider both the costs and benefits of migrating if they feel there is a net gain to be made (Pekkala, 2003; Pekkala \& Tervo, 2002). Importantly, not all the costs and benefits considered are financial: some people willingly forego economic returns for improvements in lifestyle

1 College of Business, Law and Governance, James Cook University, Cairns, Australia

2 College of Business, Law and Governance, James Cook University, Townsville, Australia

Article Info: Received: January 2, 2022. Revised: February 6, 2022. Published online: February 15, 2022 
and/or quality of life (Morrison \& Clark, 2011). As such, migration choices are influenced by a wide variety of factors.

It has been over 50 years ago since Lee's (1966) 'Theory of Migration' identified four broad groups of factors which influence the decision to migrate (characteristics of the origin, characteristics of the destination, intervening obstacles, and personal factors), and those factors are still relevant today (Lee, 1966). Characteristics of the origin and destination create 'push-pull' factors (Taylor, 1969), making some regions more or less desirable than others. But not all characteristics of all regions are readily apparent to all individuals, and not all individuals view the characteristics of all regions equally (Chen \& Rosenthal, 2008). As such it is not so much the actual characteristics of an origin and destination that influence migration decisions, but rather people's perception of those characteristics (Beine et al., 2014; Lee, 1966). Research indicates that those of higher socio-economic status may find it easier to gather information about the characteristics of, and opportunities within, potential destinations, particularly if far away (see, for example (Trovato \& Halli, 1983), so are thus more likely to move in pursuit of better opportunities; those of lower socioeconomic status may get 'trapped' within economically stagnating regions (Long, 1973).

Even if somebody believes that a potential destination is more 'desirable' than their current home (origin), $\mathrm{s}$ /he will not necessarily choose to migrate: also important are intervening obstacles such as the distance that must be travelled, actual physical and cultural barriers, immigration laws and regulations and means/costs of transport - (Bell et al., 2002; Finney \& Simpson, 2008; Hoover, 1971; Lee, 1966; Nivalainen, 2004). As for the characteristics of origins and destinations, it may not be actual obstacles that influence decisions, but rather perceptions of those obstacles. Here too, research indicates that some people find intervening obstacles more difficult to overcome than others thus also contributing to the oft-found result that people of higher socio-economic status are, all else constant, more likely to migrate than others (Eliasson et al., 2003; Long, 1973; Niedomysl, 2008; Ritchey, 1976; Trovato \& Halli, 1983), and will migrate over longer distances (Long, 1973).

Not only is socio-economic status an important determinant of migration, but so too is age. People in their late teens, twenties and early thirties are more migratory than their 'middle-aged' counterparts (Nivalainen, 2004) although those approaching retirement are also relatively mobile (Ritchey, 1976). Much of this age-effect is related to 'family-cycle' and much is related to the labour market (peak mobility at the start of a career, more stability in the middle, and increasing mobility once reaching retirement). As regards to the family cycle: household size, number/age of children (Halfacree et al., 1992; Long, 1972; Miller, 1976; Nivalainen, 2004), age of the parents and/or head of the family and marital status (Kulu \& Milewski, 2007; Long, 1992) all influence migration decisions. Marriage decreases mobility, and having children reduces mobility further (Nivalainen, 2004). This is particularly true when the children are in school (Long, 1972; Miller, 1976) and the larger the family size, the less mobile will be that family (Halfacree et al., 1992). These effects are thought to occur because the migration decision becomes more complex as the family size increases: if weighing up the costs and benefits of a move, net benefits must be deemed positive for all (Kulu \& Milewski, 2007; Long, 1992).

This highlights an issue core to this paper: when considering migration motives, whom are the motives we wish to understand? It is clearly of the migrant, but how do we define the migrant if there is more than one person involved? Is it one individual who makes the decision in isolation of the preferences of others or is it a joint decision of all of those who are affected by the decision? (Mincer, 1978; Roseman, 1971).

Hammar et al., (2021) point out that in order for micro-economic behavioural models to increase its explanatory power of migration decisions, the complexity and heterogeneity of decision makers who are influenced by families and other groups must be accommodated. Thus this paper seeks to add to this literature by representing a migration model which accounts for this complexity among decision makers as a unit, rather than a self-enlightened individual being (Hammar et al., 2021; Massey et al., 1993).

The paper is organised as follows. Section 2 presents our working definition of migration, whilst Section 
3 reviews the migration literature. We discuss our data sources and research methodology in Section 4. We present our results in Section 5, before drawing conclusions in Section 6.

\section{Defining Migration}

Before any investigation into migration can be conducted, one needs to understand what migration is, that is, why it is measured, how it is defined and what data sources are typically used to measure it? Migration is an important aspect of human behaviour (Cushing \& Poot, 2004). Its investigation is important as it provides insights into spatial patterns (human settlement), migrant selection, migration intensity and assists in population estimates/projections. All which are needed to help formulate effective policy and ensure timely provision of infrastructure and services.

Migration is "not a unique event but a continuous process across time and space" (Skeldon, 2012, p. 230). Migration is clearly a space-time phenomenon (King, 2018). As depicted within Fielding's (2012) population movement framework, it has both a temporal dimension, how long an individual stays in a new location (duration of stay), and spatial dimension, how far the individual has moved (distance travelled) (Fielding, 2012; Niedomysl \& Fransson, 2014). Investigation into both of these dimensions have their importance. Many definitions exist (Bell et al., 2002; Greenwood, 2005; Lee, 1966; Taylor, 1969) and vary in their explanations (Bell et al., 2015a and 2015b; Faggian et al., 2017) of migration. These definitions often do not differentiate/preclude whether the migration is voluntary or involuntary (however most migration models assume voluntary migration (Mangalam, 1968)), external or internal, short distance or long distance, permanent or semi-permanent, by the individual or household. What is definite is that the act of migration does not take place in vacuo (Taylor, 1969).

Nonetheless at its most basic definition and the one which we adopt for this paper, migration can be described as "a relatively permanent change in usual region of residence within Australia" (McHugh et al., 1995; White \& Lindstrom, 2005). However, while this definition, as per many others, considers both the temporal and spatial dimension to migration, it does not address by whom. Whilst the definition does not exclude the movement of a 'collective of people', migration is often implicitly thought of as an individual activity (Mangalam, 1968). Thus this 'social' dimension to migration can be overlooked.

Therefore, in addition to the temporal and spatial aspect of population movement (as per Fielding's (2012) and Bell and Ward's (2000) frameworks), we consider a third dimension, the social resolution (Bell \& Ward, 2000; Fielding, 2012). Here we investigate who is the unit which makes the decision to move? We see that over time this unit shifts from the individual seen in Sjaastad's (1962) human capital framework, to a collective body such as the family in Mincer's (1978) model (Mincer, 1978; Sjaastad, 1962). Here too we witness a change where the traditional meaning given to 'family' is contested by what is witnessed in today's existing alternative 'family' structures. Therefore, nonfamily or another more appropriate term to represent the collective unit must be considered instead.

\section{Literature Review}

Early theory of migration is embodied in the literature of human capital. Neoclassical economists have long argued that migration is an investment, a means by which individuals can maximise their utility function. An investment in the same sense that education or training would have on one's potential earnings. These are investments in human capital where individuals are making investments in their human resources by devoting time to activities whose benefits accrue in the future (Nivalainen, 2004).

This neoclassical approach is based on the assumption that individuals a) act rationally and 2) set out to maximise their utility (Hammar et al., 2021; Massey et al., 1993; Ritsilä \& Ovaskainen, 2001; Sjaastad, 1962). The decision to migrate, therefore, is not a random event. The economic actor evaluates the expected returns of moving and staying (Greenwood, 1997; Smits, 2001) and decides to move if the 
differences in these expected returns outweigh the costs of moving. But is the economic actor (traditionally noted as the 'man' of the household for reasons outlined later) rational in 'his' decision process and do they always set out to maximise utility? The 'rigidity' inherent within classical theories on migration, which view migrants as rational utility maximisers, has received criticism (Hammar et al., 2021; Kopnina-Geyer, 1998; Massey et al., 1993). There lies an assumption that all information and limitations are known from which the migrant problem solves to select the best choice. However rather than an autonomous human being, they, the migrants are part of a heterogeneous group, embedded in a social context (Kopnina-Geyer, 1998, p. 101; Massey et al., 1993).

By default, labour migration comes to be defined as a 'good thing' (Boyle et al., 2001), usually assumed to be associated with economic betterment. Although as we will see later, this betterment may not be the case for all members of the migrant 'unit'(Smith, 2004).

Thus, this framework and the empirical literature following it, largely emphasises the monetary component to migrating, with differences in wages being the main drivers of migration. However as Smith (2004) points out the "focus on economic-related outcomes may signify a pragmatic response to the limitations of quantitative data" (Smith, 2004, p. 267). Thus, should a migrant decide to 'downsize' or drop out of the labour force for personal 'quality of life' reasons, do we deem them illogical or 'irrational', in at least the economic sense?

Mincer's family migration model signifies an important development in the literature, where utility decisions such as 'individual tastes, amenities, and social and cultural networks' are given consideration. This theory states that the "costs and returns [of family migration] should be understood to include both monetary and nonmonetary components" (Mincer, 1978, p. 750).

Thus, we see two important developments in the migration theory, an explicit inclusion of non-monetary components and the distinction between individual decision making and that of the household or family. In Mincer's (1978) model it is explicitly recognised that net family gain rather than net personal gain is the driver for migration decisions (Smith, 2004). In addition, while migration may be beneficial economically for single individuals, it may not be for partnered individuals (Boyle et al., 2001). There may be personal losses, but these are weighed against the overall gain to the family.

These 'losers' of migration are represented by Mincer's (1978) migration ties; the tied mover, where the household moves, even though one partner does not prefer this move and the tied stayer; where no move is undertaken although one partner preferred to move (Cooke, 2003; Mulder \& Wagner, 1993). Often it is the woman (the wives) depicted as the 'tied mover' (the trailing wife), where any gains to the household were seen to have come at the expense of the wife's career (Geist \& McManus, 2012; Sandell, 1977). It is important to highlight here that while earlier studies showed women's wages suffered following family migration, to assume they 'lost out' or were 'losers' of migration may not be entirely accurate.

Such ambiguity may be a reflection of the limitation set by the use of quantitative datasets and their research questions. Without qualitative responses which specifically address social, cultural and psychological motives for moving or not, researchers are limited by what can be interpreted from the data (Bell et al., 2015a; Bell et al., 2015b). Consequently, concluding the 'trailing wife' 'lost out' in the decision process.

More information may in fact show that a 'quality of life' choice was the motivation, whereby these women, 'mothers' for example, choose to stay at home and moving afforded them that choice. So the 'trailing wife' in this case may not necessarily be a 'bad' thing but rather a decision which was made consciously. These life course events such as childrearing, marriage or home-making are all potential triggers of migration.

These early developments in the migration literature which are embodied in the human capital approach, signify the importance of the 'family'. But what is the 'family'? The term 'family' is defined as "a social network, not necessarily localised, that is based on culturally recognised biological and marital 
relationships" (Waite, 2005, p. 463). To what extent is this however, an accurate representation of what is given by the meaning of family today? How do alternative structures fit into this mold?

In this definition above the term family is constrained by 'biological and marital relationships' which highlights potential issues. Does there need to be a marriage particularly when cohabitation and non-marital childbearing are increasingly common? In some countries cohabitation is a permanent alternative to marriage (Sassler \& Lichter, 2020). Take Norway and Sweden where cohabitation has the same legal and social status as marriage (Waite, 2005).

As for 'biological relationships', must couples bear and raise children? How should we consider couples who live with their children and/or those from previous relationships? This is by no means a new alternative family structure. With early widowhood come remarriages, stepfamilies and single-parent families (Biblarz \& Gottainer, 2000). Then there are same-sex couples raising children. These unions are now commonly recognised legally through marriage in countries such as Australia, New Zealand, Germany and Malta, to name a few. Furthermore child custody rights have been extended to same-sex couples in Denmark, Canada and the Netherlands (Kolk \& Andersson, 2020).

Then there is the extended family unit to consider, where we see elderly parents living with their children and/or adult children living with their parents (Elder et al., 2003). This surfaces another emerging trend of dual career couples, where both partners are working in managerial, professional or associate professional occupations (Hardill et al., 1997, p. 316). Here we see at least two contrasting scenarios. Firstly that of the extended family unit mentioned where the couple's elderly parents cohabitate with their children and assist with child rearing needs while their children focus on their careers (Bailey et al., 2004; Elder et al., 2003). While the other scenario, childless couples, where both partners are career driven and bear no children. Hardill et al. (1997) go as far as to say that "In light of the declining number of 'nuclear' families and the rising number of childless couples with 'top jobs' it seems appropriate to focus on 'households' rather than 'families',' (Hardill et al., 1997, p. 317).

In light of the constraints given by the term 'family', is the household the appropriate unit of analysis as Hardill et al. (1997) mention? The household is defined 'as one or a group of persons who normally live together in a single unit of housing' (Roseman, 1971). As Roseman (1971) explains:

An individual living alone thus comprises the smallest unit, his migration decisions affecting only himself. At the other extreme, a married couple with a dozen children plus several relatives may move as a unit, one decision governing the migration of all members of the household (Roseman, 1971, p. 591).

This definition however, as also given by the Australian Bureau of Statistics (ABS) (one or more persons usually resident in same private dwelling) does not exclude unrelated individuals living together such as in a boarding house. By not excluding these types of households, it is difficult to ascertain what type/s of relationships each have to one another and what influence a permanent decision such as migration would have on these cohabitating persons. Therefore our unit of analysis must be one which reflects a cohesive unit (if not single) where the relationships between each of the members are interdependent on one another. An interdependency, similar to how Roseman (1971) has described, where a decision governs all. Ambiguity still remains however on how the migration decision is derived. Whether it is made jointly or by an individual representative of the unit such as the 'head of the household'.

In decision making we see three types of couples; leaders, followers and egalitarians (Hardill et al., 1997). Traditionally (studies from 1970/80s) the male was often seen as the head of the household as historically he commanded a higher wage (the breadwinner). He would 'lead' with his career while the female followed. Thus where the couple lived was dependent on the male's decision as any career-related decisions were made by the husband while housekeeping decisions made by the wife (Hardill et al., 1997). However with the rise of dual-careers (Green, 1997; Hardill et al., 1997, p. 323), the household head is obsolete and an egalitarian approach to decision making is more likely to be adopted. Moreover, these 
positions are much more fluid in households today with couples changing their roles along the continuum at different stages of their lives (Hardill et al., 1997, p. 322).

In light of all the emerging non-family structures and uncertainty of the types of relationships which umbrella under the term 'household', it seems appropriate that an alternative term be given to describe our unit of analysis. We therefore term Decision Making Unit (DM Unit) to describe this cohesive unit. It is inclusive of traditional and (some) alternative, albeit self-identified family structures, singles (termed single DM Unit) and multi-persons (multi DM Unit) (Section 4 further explains this distinction).

In the following section we describe our data source and 'how' we conform our dataset to reflect this DM Unit and all that embodies it.

\section{Methodology}

Other than surveys, two common instruments used to collect migration data are population censuses and population register/administrative records (Bell et al., 2015a). Although in recent years countries are beginning to adopt a hybrid approach which involve register-based censuses (e.g. Denmark. Finland, Norway and Sweden) or combined censuses (e.g. Czech Republic, Estonia, Italy and Switzerland to name a few) which link data from registers and surveys (Bell et al., 2015b; Coleman, 2013). These sources measure changes of residence either as transitions or as events (Bell, 1996, 2003; Bell et al., 2002; Blake et al., 2000; Newbold \& Bell, 2001). National censuses often provide transition data, allowing one to identify migrants by comparing their place of usual residence at the time of enumeration $(t)$ with that at a specified earlier date (t-n) (Bell et al., 2002, p. 437). Population registers deal with 'event data', typically recording every move (event) made by an individual, thus capturing multiple and return migrations as well as moves by newborns and those just before death (Bell, 1996, 2003; Bell et al., 2002; Blake et al., 2000; Newbold \& Bell, 2001).

This highlights a limitation of using National censuses (for Australia the quinquennial Census of Population Housing). They fail to capture lifetime movement as they do not collect data on place of birth for the native born, nor multiple and return moves, and any migrants that are born or die during the interval period. However, it has been noted that using previous place of residence, as provided by transition data, may better reflect location specific capital and ties to place (DaVanzo, 1978; Newbold \& Bell, 2001) than place of birth. Further, information on place of birth may not provide a reliable proxy for lifetime movement as increasing proportions of children are being born in hospitals from larger towns or cities rather than where they actually live (Skeldon, 2012). These places may be smaller, remote towns that were not able to provide the health services needed (Skeldon, 2012). As such drawing any meaningful insights on the population distribution between rural and urban areas will be compromised given the place of birth data is not entirely representative of where the person may/may not have migrated from.

Moreover population registers/administrative records, such as electoral rolls and Medicare records for Australia, whilst provide continuous monitoring on movement (White \& Lindstrom, 2005) and thus a capacity to construct longitudinal data (Bell et al., 2015a) they contain less information on the individual's characteristics (sometimes omitting some groups altogether). Further, they generally contain coarser geographical units compared to National census (generally coded at the regional and local level), failing to capture information on within-region moves and often lags in registration (Bell, 1996; Newbold \& Bell, 2001). Population Registers feature more strongly across Europe and East Asia, where a rich source of migration studies have come from (Bell et al., 2015b).

Blake et al. (2000) state that the quinquennial Census of Population and Housing is the "only comprehensive source of information on internal migration in Australia" (Blake et al., 2000, p. 158). We used data from the Australian Bureau of Statistics's 1\% Basic Census Sample File which contains confidentialised unit record data on 199,406 persons from 48 Australian regions, collected on the $8^{\text {th }}$ of 
August, 2006. Each unit-record identified the 'region' in which an individual lived during 2006 and during 2001. Following the lead of other researchers working with transition data (e.g. Bell et al., 2002), persons who lived in the same region at both points of time were categorised a non-migrant; those who lived in different regions were categorised as migrants $\mathrm{s}^{3,4}$.

The dataset was then restructured, essentially ensuring that each row contained information about all individuals within a single DM unit (rather than information about a single individual). This methodological approach is not too dissimilar to Nivalainen's (2004) husband-wife migration study which utilised Finnish census data and that of Boyle et al. (2001) who utilized census microdata from Great Britain and the United States, both of which merged men and women belonging to the same family to obtain a single observation unit (Boyle et al., 2001; Nivalainen, 2004). However, unlike Nivalainen (2004), we also observe migration patterns of singles and multi-person DM units greater than two-persons. Thus, our migration rates will be higher than Nivalainen's (2004) but below that of the population for reasons we outline below.

We were, however, limited by the fact that the data set contained much information about DM unit composition during 2006, but did not contain any information about DM unit composition during 2001. So we identified DM units where all individuals within it (who thus lived together in 2006 and self-identified as a unit) had also lived (presumably together) in the same region in 2001. The entire DM unit was thus categorised as either a migrant or a non-migrant DM unit depending upon the mover/stayer status of (all) individuals within it. Other potential DM units (i.e. those where different members had lived in different regions five years previously) were excluded from the analysis, since we had insufficient data to control for these changes. Consequently, this approach does not allow us to identify the role that changes to DM unit composition (e.g. divorce, marriage, newborns) have upon migration, an important issue for future research. As such, as all our DM Unit characteristics are measured at the census date 2006, they represent outcomes after migration, and do not reflect the situation of the DM Unit prior to it. Statistically this raises the potential issue of reverse causality (the migration decision affecting DM Unit characteristics rather than the other way around) causing endogeneity.

We further omit DM units with children who were under five years of age during 2006, which are generally excluded as they were not alive at the start of the interval (Bell, 1996).

As per Bell and Stratton (1998) recommendations:

census-based analyses of migration should exclude people who failed to state their previous address, overseas visitors, children born during the observation period and current residents who were overseas at the start of the migration interval (Bell \& Stratton, 1998, p. 167).

Given migration is triggered by life course events, the exclusion of this group may underestimate the migration rate given DM Units with younger children as opposed to school-aged children are more mobile (Kulu, 2008).

\footnotetext{
${ }^{3}$ Importantly, this approach fails to differentiate between those who moved only once, and those who moved several times. It also fails to identify people who moved within a region. This is not a problem in the geographically small and densely populated urban areas where such moves are not likely to reflect 'migration' (instead reflecting changed housing), but it fails to identify people who may have moved long distances in the larger, geographic regions that prevail in rural Australia.

${ }^{4}$ The variables of interest for this measure relate to where the unit resided on census night (REGUCP) and five years previously (REGUC5P). Here we identify (1) a migrant DM Unit if there is a difference between the variable REGUCP (Region of Usual Place of residence on Census night) and REGUC5P (Region of Usual residence five years ago) and (2) a non-migrant DM Unit if there is no difference.
} 
In summary our dataset is stratified to include DM Units who were:

- living in the same dwelling on census night 2006;

- singles or self-identified families (as recorded by ABS Family, Household and Individual identification variables); and

- also living in the same region five years ago (presumed, to be the same dwelling, but data do not allow us to confirm that).

We note that our DM Unit does not perfectly align to either definition given by the ABS for 'household' or 'family'. To reiterate, the ABS definition for household (one or more persons, at least one of whom is at least 15 years of age, usually resident in the same private dwelling) includes all persons cohabiting together whether they are related or not (e.g. boarders). These cohabiting, unrelated individuals who self-identify themselves as not being part of this immediate 'family' (under the ABS definition) are separated into different DM Units in our analysis.

As for 'family', the ABS defines it as "two or more persons, one of whom is at least 15 years of age who are related by blood, marriage (de-facto or registered), adoption, step or fostering, who are usually resident in the same household"(Australian Bureau of Statistics, 2016). Non-related persons living in the same household are not counted as family members unless they are under 15 years. While our DM Unit is more closely aligned to this definition it is not equal to it as single persons are exempt from the ABS definition.

In addition, while a dwelling can contain multiple families (as per ABS definition) our DM unit reflects only one family per observation unit. Thus each family is separated into their own DM Unit (row) (see figure 1 for an example). In summary, we grouped only those persons who, on the 2006 census night (a) were living in the same dwelling and (b) identified as being part of the same 'family' (Figure 1).

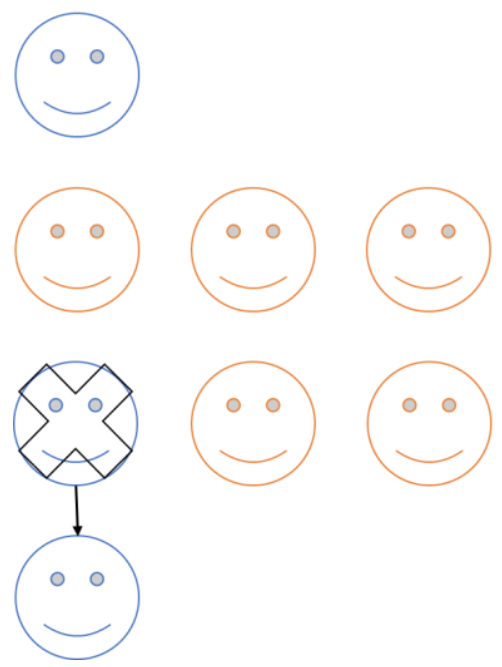

\begin{abstract}
An individual living alone. This individual forms a single DM Unit.
\end{abstract}

Three related individuals living together. All three form a multi DM Unit

Three individuals living together one who is unrelated. The unrelated individual forms a single DM Unit while the two related form a multi DM unit.

Figure 1: Decision Making Unit

Our final dataset thus contained information on 56,564 DM units, $14.6 \%(8,257)$ of which had moved, as a cohesive group from one region to another, the remainder had stayed together as a cohesive group within a single region (see Table 1 for DM Unit descriptives). 


\subsection{Defining characteristics of the DM unit}

As regards the independent variables, we used variables that intend to capture essential characteristics of the entire DM Unit rather than the head of the DM Unit.

As highlighted within the literature review, age is strongly linked to life cycles or life courses which are also linked to mobility patterns. In previous neo-classical models, the age of the head of the household has been used. To capture age, we included two variables. We used the log of the age of the eldest person in the household (Log Age of Eldest) to capture the relationship that exists between age and mobility and the $\log$ to capture non-linearity (Eliasson et al., 2003; Eliasson et al., 2014). Whilst the minimum or average may have been used as proxies, the maximum age was used to capture these life course changes. Additionally, we constructed a dummy variable for DM Units with School-aged children to capture the associated social ties to communities.

Further, we used variables for DM unit income, which is the sum of all weekly income generated by DM Unit members (Income), the Number of Employed adults in the DM unit and number of persons in the DM Unit (Size of DM Unit). Whilst household income and household size are variables which researchers have adopted to capture the 'family', employment has more often been limited to the individual or in some recent literature, the wife and husband. This ignores the influence of other household members whose employment situation may impact decision making. Thus, we use a numeric variable which captures the number of employed individuals within that unit. We also included a dummy variable Defence DM Unit, since members of the Australian Defence Force move regularly as part of their job. We include this variable as a control variable. The same applies to DM units that include a person who works in the mining industry. Miners also move more regularly for work reasons, hence the inclusion of the dummy variable Mining DM Unit.

Education has been measured by researchers using: years of schooling (Vijverberg, 1993); or categories of schooling (e.g. where highest education is secondary, school, university or $\mathrm{PhD}$ ) (Pissarides \& Wadsworth, 1989) or dummy variables to distinguish those that have graduated from university (Bachelor upwards) and those who have not (Irwin et al., 2004). Recognising that it is not just the educational level of the 'head' of the DM Unit that is likely to influence mobility, we used three variables to represent DM Unit education. First, University degree is a dummy variable which indicates whether there is at least one adult in the DM Unit who graduated from university (1) or none (0). Second, Years of Schooling Concentration, for which we use data relating to the ABS census question regarding the highest non-school qualification obtained. In the first place, we converted these categorical responses into years of schooling, to obtain information about the total years of schooling of each adult within each DM Unit (see Table 1).

We then calculated a Years of Schooling Concentration variable, which is, essentially, a Herfindahl-Hirschman type of Index:

$$
\text { Years of Schooling Concentration }=\sum_{i=1}^{k}\left(\frac{[\text { years of schooling }]_{i}}{\sum_{i=1}^{k}[\text { years of schooling }]_{i}}\right)^{2}
$$

Where

$i$ represents an adult member of the DM Unit and

$k$ the total number of adults in the DM Unit.

Although traditionally used to measure the relative share in a defined market (Rhoades, 1993), the Herfindahl-Hirschman Index (HHI) offers a wide application since it measures the level of diversity, represented within a ratio. This 'market' can be interchanged for many different areas, not just industry or business. It can look at different degrees of concentrations of human populations and cultural diversity (considering share of employees with nationality among all employees of a region (Niebuhr, 2010)). It also has been used to assess the distribution of electronic gaming machines (Sargent \& Holmes, 2014). 
Within the migration context, it has been used to measure the level of diversity of immigrant birth countries and global spread of migrants across migration corridors (Borjas \& Bratsberg, 1996; Czaika \& De Haas, 2014). In the context of human capital, a variant of HHI looked at the diversity index of high-skilled employment, measuring the degree of specialisation of the surrounding human capital in other industries in the same location (Blien et al., 2006). However, no one, to the best of the authors' knowledge, has HHI used in this context which is to look at the spread of education across members of a social unit, such as the DM Unit.

If all years of schooling in the DM Unit are held by one person, this concentration index will equal one. If more than one person in the DM Unit hold years of schooling, the concentration index will be less than one.

It is commonly accepted amongst migration research that individuals with higher levels of education attainment are in a better position to seek opportunities which further enhance their lives (migrating including). Thus, the third DM Unit education variable we use is an interactive dummy: University Degree multiplied by Years of Schooling Concentration. This interaction variable is included to capture the 'power couple' phenomenon. 'Power couples' are those in which both spouses have university degrees. Such couples have been found to be more migratory than 'low-power couples' (both without degrees) (Compton \& Pollak, 2007). Both power and low-power couples have similar (low) Years of Schooling Concentration scores. Hence if power couples are more likely to move than low-power couples, the interaction variable should be negative in the regression analysis.

Lastly, a novel categorical variable capturing the religious status of the DM Unit (three categories: Non-religious and Some not all Religious and Religious) is included to capture the effect religion may have on migration. Within our migration model, a DM Unit was classified Religious if all members identified as being affiliated to a religion (e.g. Catholic, Buddhism, or Pentecostal). DM Units for which every member indicated 'no religion' was classified Non-religious, while mixed responses amongst DM Unit members were coded Some not all Religious. Religious diversity/tolerance has been identified as an area which warrants further investigation in migration studies (Cushing \& Poot, 2004). To the best of our knowledge there are only two papers which have used a measure to represent religion to empirically investigate this relationship. The first paper by Myers (2000) claims to be the first and only paper which has modelled this relationship whilst the second paper by Kulu (2008) researches the effect of fertility on migration rates and thus includes religion indirectly to help explain this relationship. Whilst religion is often associated with 'worship' and a person's belief in a god or higher being, it is its unification amongst a group of people which create a sense of belonging to this community. Thus, greater involvements in the social aspects of one's religious organisation may deter migration (Dawkins, 2006). That is, we expect religious DM Units to be less likely to move compared to those that are mixed or non-religious.

Recognising that several of these variables are redundant for single-person households, we ran two separate logistic regressions.

Single DM Units:

Migrant $=\mathrm{f}($ Log Age of Eldest, Income, Number of Employed, Defence DM Unit, Mining DM Unit, University Degree, Non-Religious).

Multiple DM Units:

Migrant $=\mathrm{f}($ Log Age of Eldest, School-aged children, Income, Number of Employed, Size of DM Unit, Defence DM Unit, Mining DM Unit, University Degree, Years of Schooling Concentration, University Degree X Years of Schooling Concentration, Non-Religious, Some, not all Religious). 
Table 1: Variable definitions and descriptive statistics

\begin{tabular}{|c|c|c|c|c|c|}
\hline Variable name & Variable definition & Mean & St Dev & Min & Max \\
\hline Migrant (1 of yes) & $\begin{array}{l}\text { All members of the } 2006 \text { DM Unit resided in a different region in } \\
2001\end{array}$ & 0.14 & 0.34 & 0 & 1 \\
\hline Log Age of Eldest & Log of the age of the eldest person in the DM Unit & 3.93 & 0.35 & 2.70 & 4.45 \\
\hline School-aged children ( 1 if yes) & $\begin{array}{l}\text { DM Unit contains children in primary or secondary school, } \\
\text { measured by the age of the child }\end{array}$ & 0.42 & 0.49 & 0 & 1 \\
\hline Income & Sum of all individual adult weekly income in the DM Unit & 1,043 & 854 & 0 & 7,803 \\
\hline Number of Employed & Number of adults employed in the DM Unit & 1.06 & 1.00 & 0 & 6 \\
\hline Size of DM Unit & Number of individuals in the DM Unit & 2.10 & 1.20 & 1 & 7 \\
\hline - Single DM Unit ( 1 if yes) & The DM Unit comprises of one person & 0.38 & & & \\
\hline - Multi DM Unit ( 1 if yes) & The DM Unit comprises of multiple persons & 0.62 & & & \\
\hline Defence DM Unit (1 if yes) & $\begin{array}{l}\text { At least one member of the DM Unit employed by the } \\
\text { Commonwealth under occupation 'Community and Personal } \\
\text { Service workers' as defined by the ABS }\end{array}$ & 0.02 & 0.12 & 0 & 1 \\
\hline Mining DM Unit (1 if yes) & At least one member of the DM Unit employed as a miner & 0.01 & 0.10 & 0 & 1 \\
\hline University degree ( 1 if yes) & At least one adult member of the DM Unit completed university & 0.20 & 0.40 & 0 & 1 \\
\hline $\begin{array}{l}\text { Years of Schooling } \\
\text { Concentration }\end{array}$ & See Section 4.1 for a detailed explanation & 0.65 & 0.32 & 0 & 1 \\
\hline Religiosity & DM Unit contains individuals who identify as religious or not & & & & \\
\hline - Non-Religious & None of the DM Unit members identify as religious & 0.15 & & & \\
\hline - Some, not all Religious & Some, not all of the DM Unit members identify as religious & 0.08 & & & \\
\hline - All Religious & All DM Unit members identify as religious & 0.77 & & & \\
\hline
\end{tabular}




\section{Results}

Table 2 provides key regression results. In both models all variables, with the exception of Mining DM Unit in both models and Income and University degree X Years of Schooling concentration, in multi DM Units, are statistically significant at the $10 \%$ confidence interval level.

Our results are consistent with conventional studies, which show that smaller, younger households are more likely to move than larger households (Halfacree et al., 1992; Sandefur \& Scott, 1981) demonstrated by the negative and statistically significant coefficients on the variables capturing: Log Age of Eldest, School-aged children and Size of DM Unit.

Table 2: Logistic regression of the DM unit-related drivers of internal migration (for single and multi DM units)

\begin{tabular}{|c|c|c|}
\hline Independent variables & Single DM unit & Multi DM unit \\
\hline Log Age of Eldest & $\begin{array}{c}-1.56^{* * * *} \\
(0.05)\end{array}$ & $\begin{array}{c}-1.71 * * * \\
(0.06)\end{array}$ \\
\hline School-aged children ( 1 if yes) & & $\begin{array}{c}-0.19 * * \\
(0.06)\end{array}$ \\
\hline Income & $\begin{array}{l}0.00 * * \\
(0.00)\end{array}$ & $\begin{array}{c}0.00 \\
(0.00)\end{array}$ \\
\hline Number of Employed & $\begin{array}{l}-0.07 * \\
(0.05)\end{array}$ & $\begin{array}{c}-0.21 * * * \\
(0.03)\end{array}$ \\
\hline Size of DM Unit & & $\begin{array}{c}-0.07 * * \\
(0.03)\end{array}$ \\
\hline Defence DM Unit (1 if yes) & $\begin{array}{c}0.87 * * * \\
(0.10)\end{array}$ & $\begin{array}{c}0.24 \\
(0.12)\end{array}$ \\
\hline Mining DM Unit (1 if yes) & $\begin{array}{c}0.24 \\
(0.15)\end{array}$ & $\begin{array}{c}0.2112 \\
(0.15)\end{array}$ \\
\hline University Degree ( 1 if yes) & $\begin{array}{c}0.42 * * * \\
(0.05)\end{array}$ & $\begin{array}{c}0.38 * * \\
(0.12)\end{array}$ \\
\hline Years of Schooling Concentration & & $\begin{array}{c}0.44 * * * \\
(0.10)\end{array}$ \\
\hline University Degree X Years of Schooling Concentration & & $\begin{array}{l}-0.00 \\
(0.21)\end{array}$ \\
\hline \multicolumn{3}{|l|}{ Religiosity DM Unit } \\
\hline - Non-Religious & $\begin{array}{l}0.08^{*} \\
(0.04)\end{array}$ & $\begin{array}{l}0.15 * * \\
(0.05)\end{array}$ \\
\hline - Some, not all Religious & & $\begin{array}{c}0.06 \\
(0.05)\end{array}$ \\
\hline - All Religious & reference & reference \\
\hline Constant & $\begin{array}{c}4.37 * * * \\
(0.18)\end{array}$ & $\begin{array}{c}4.67 * * * \\
(0.27)\end{array}$ \\
\hline Log-Likelihood & -9318.8865 & -10902.961 \\
\hline Adjusted R-squared & 0.0901 & 0.0478 \\
\hline Sample size & 21,157 & 34,516 \\
\hline
\end{tabular}

Notes: Standard errors in parentheses; *,**, *** denote significance at $1 \%, 5 \%$ and $10 \%$ level, respectively 
Our findings also corroborate other research which indicates that education (in this case, the presence of at least one university degree in the household) is positively correlated with mobility (Eliasson et al., 2003; Long, 1973; Niedomysl, 2008; Ritchey, 1976; Trovato \& Halli, 1983). However, our coefficient on Years of Schooling Concentration, unique to that of other researchers (which involves all adults), indicates that DM Units which have high concentration levels of educational attainment (that is, closer to one) are more likely to move than DM Units, which have low concentration levels of educational attainment. We find no evidence to support that the concentration level of educational attainment is more important for highly educated DM units (for example high-powered couples). Further, Number of Employed Persons is also negatively correlated with mobility indicating that a move is less likely in DM Units that have more employed persons (for single DM Units indicating the unemployed is more likely to move).

As expected, having a higher income makes a single DM Unit more mobile as does being in the Defence Force. These effects do not extend to multi DM units.

Social ties to a place have been represented by our religiosity variable, which have been rarely used by researchers in this field. Our hypothesis that those DM Units that are all religious are less mobile than those who are partial or not at all altogether is supported with results indicating that DM Units that are Non-religious (both single and multi DM units) are more mobile than those DM Units where all members are religious (reference category).

\section{Conclusions}

Much migration research considers the characteristics of an individual, the characteristics of the "head of a household' and some general descriptors of the household in which an individual is embedded (e.g. household size). Its foundations embedded in neo-classical theory of migration which states that individuals are in pursuit of self-interest and both autonomous and rational in their decision making. The 'new economics of migration' literature highlights the pitfalls of such assumptions, however empirically we are yet to witness a methodology which collectively captures characteristics of the whole decision making unit. This paper seeks to fill this gap within the literature by demonstrating a method of transforming individual-level census data to construct variables that measure both 'standard' household characteristics and more innovative household characteristics related to both the human and social capital of all within that household, termed the decision making unit (DM Unit).

This has enabled us to determine that (for this data set at least) a DM Unit in which at least one person has a university degree, is more likely to have moved during the previous five years than a DM Unit in which no-one has a university degree. Moreover, DM Units which have high concentration levels of educational attainment are more likely to have moved during the previous five years than DM Units which have low concentration levels of educational attainment. In the latter type of DM unit, educational attainment is spread among multiple members, who-when considering moving - are likely to require more than one job in the destination area. This finding suggests that Australian regions or employers who wish to attract or retain workers from DM units with low concentration levels of educational attainment, may need to provide opportunities for more than just a 'head of household'. We find no evidence that this phenomenon is particularly relevant for high-powered couples. The results are clearly context specific, but the statistical significance of our concentration variable highlights the importance of ensuring that migration studies include variables that describe characteristics of the entire decision making unit, not just an individual within it, or a presumed 'head of household'. Also important, are the characteristics of regions (both origins and destinations) and of 'intervening obstacles' (Lee, 1966). Modern research has found that highly skilled persons seem to place less importance on regional costs such as housing, tax rates and health care and place greater weight on cultural facilities and natural amenities such as coastal area and water view (Niedomysl, 2008). Furthermore, regions with an attractive people climate ('bohemians') are said to spur on innovation which in turn attracts more highly skilled people (Castorina et al., 2010; Corcoran et al., 2010; Eliasson et al., 2003; Florida, 2002; Jackman \& Savouri, 1992). These 
issues stand as vitally important topics for future research for those interested in finding ways of redressing regional/rural skill shortages.

ACKNOWLEDGEMENTS. We thank Natalie Stoeckl for earlier contributions to this research.

\section{References}

Australian Bureau of Statistics. (2016). 2901.0 - Census of Population and Housing: Census Dictionary, 2016 Retrieved from https://www.abs.gov.au/ausstats/abs@.nsf/Lookup/2901.0Chapter32102016

Bailey, A. J., Blake, M. K., \& Cooke, T. J. (2004). Migration, care, and the linked lives of dual-earner households. Environment and Planning A, 36(9), 1617-1632.

Beine, M., Noël, R., \& Ragot, L. (2014). Determinants of the international mobility of students. Economics of Education Review, 41(0), 40-54. https://doi.org/http://dx.doi.org/10.1016/j.econedurev.2014.03.003

Bell, M. (1996). How often do Australians move? Alternative measures of population mobility. Journal of the Australian Population Association, 13(2), 101-124.

Bell, M. (2003). Comparing internal migration between countries: Measures, data sources and results.

Bell, M., Blake, M., Boyle, P., Duke-Williams, O., Rees, P., Stillwell, J., \& Hugo, G. (2002). Cross-National Comparison of Internal Migration: Issues and Measures. Journal of the Royal Statistical Society. Series A (Statistics in Society), 165(3), 435-464. http://www.jstor.org/stable/3559697

Bell, M., Charles-Edwards, E., Kupiszewska, D., Kupiszewski, M., Stillwell, J., \& Zhu, Y. (2015a). Internal Migration Data Around the World: Assessing Contemporary Practice. Population, Space and Place, 21(1), 1-17. https://doi.org/10.1002/psp.1848

Bell, M., Charles-Edwards, E., Ueffing, P., Stillwell, J., Kupiszewski, M., \& Kupiszewska, D. (2015b). Internal migration and development: Comparing migration intensities around the world. Population and Development Review, 41(1), 33-58.

Bell, M., \& Stratton, M. (1998). Understanding the 1996 Census migration data. Journal of the Australian Population Association, 15(2), 155-169.

Bell, M., \& Ward, G. (2000). Comparing temporary mobility with permanent migration. Tourism Geographies, 2(1), 87-107. https://doi.org/10.1080/146166800363466

Biblarz, T. J., \& Gottainer, G. (2000). Family Structure and Children's Success: A Comparison of Widowed and Divorced Single-Mother Families. Journal of Marriage and Family, 62(2), 533-548. http://www.jstor.org/stable/1566757

Blake, M., Bell, M., \& Rees, P. (2000). Creating a temporally consistent spatial framework for the analysis of inter-regional migration in Australia. International Journal of Population Geography, 6(2), 155-174.

Blien, U., Suedekum, J., \& Wolf, K. (2006). Local employment growth in West Germany: A dynamic panel approach. Labour Economics, 13(4), 445-458.

Borjas, G. J., \& Bratsberg, B. (1996). Who leaves? The outmigration of the foreign-born. Review of Economics and Statistics, 78(1), 165-176. <Go to ISI>://WOS:A1996UH15800014

Boyle, P., Cooke, T. J., Halfacree, K., \& Smith, D. (2001). A Cross-National Comparison of the Impact of Family Migration on Women's Employment Status. Demography, 38(2), 201-213. https://doi.org/10.2307/3088301

Castorina, D., Stoeckl, N., \& Welters, R. (2010, 2 - 3 December). Internal migration in Australia: Does it exacerbate or mitigate regional skills disparities? 12th Path to Full Employment Conference, Newcastle. NSW, Australia.

Chen, Y., \& Rosenthal, S. S. (2008). Local amenities and life-cycle migration: Do people move for jobs 
or fun? Journal of Urban Economics, 64(3), 519-537.

http://www.sciencedirect.com/science/article/B6WMG-4SP3SKN-1/2/5dbecdd115b58d9a6527e3 dfb19e2c57

Chi, G., \& Voss, P. (2005). Migration decision-making: a hierarchical regression approach. Journal of Regional Analysis and Policy, 35(2), 11-22.

Coleman, D. (2013). The twilight of the census. Population and Development Review, 38, 334-351.

Compton, J., \& Pollak, R. A. (2007). Why Are Power Couples Increasingly Concentrated in Large Metropolitan Areas? Journal of Labor Economics, 25(3), 475-512. http://www.jstor.org/stable/10.1086/512706

Cooke, T. J. (2003). Family migration and the relative earnings of husbands and wives [Article]. Annals of the Association of American Geographers, 93(2), 338-349. https://doi.org/10.1111/1467-8306.9302005

Corcoran, J., Faggian, A., \& McCann, P. (2010). Human Capital in Remote and Rural Australia: The Role of Graduate Migration. Growth and Change, 41(2), 192-220. https://doi.org/10.1111/j.1468-2257.2010.00525.x

Cushing, B., \& Poot, J. (2004). Crossing boundaries and borders: Regional science advances in migration modelling. Papers in Regional Science, 83(1), 317-338. https://doi.org/10.1007/s10110-003-0188-5

Czaika, M., \& De Haas, H. (2014). The globalization of migration: Has the world become more migratory? International Migration Review, 48(2), 283-323.

DaVanzo, J. (1978). Does Unemployment Affect Migration? Evidence from Micro Data. The Review of Economics and Statistics, 60(4), 504-514. https://doi.org/10.2307/1924242

Dawkins, C. J. (2006). Are Social Networks the Ties that Bind Families to Neighborhoods? Housing Studies, 21(6), 867-881. https://doi.org/10.1080/02673030600917776

Elder, G. H., Johnson, M. K., \& Crosnoe, R. (2003). The Emergence and Development of Life Course Theory. In J. T. Mortimer \& M. J. Shanahan (Eds.), Handbook of the Life Course (pp. 3-19). Springer US. https://doi.org/10.1007/978-0-306-48247-2_1

Eliasson, K., Lindgren, U., \& Westerlund, O. (2003). Geographical Labour Mobility: Migration or Commuting? Regional Studies, 37(8), 827 - 837. http://www.informaworld.com/10.1080/0034340032000128749

Eliasson, K., Nakosteen, R., Westerlund, O., \& Zimmer, M. (2014). All in the family: Self-selection and migration by couples. Papers in Regional Science, 93(1), 101-124. https://doi.org/10.1111/j.1435-5957.2012.00473.x

Faggian, A., Rajbhandari, I., \& Dotzel, K. R. (2017). The interregional migration of human capital and its regional consequences: a review. Regional Studies, 51(1), 128-143. https://doi.org/10.1080/00343404.2016.1263388

Fielding, A. (2012). Migration in Britain paradoxes of the present, prospects for the future (Vol. null).

Finney, N., \& Simpson, L. (2008). Internal migration and ethnic groups: evidence for Britain from the 2001 Census. Population, Space and Place, 14(2), 63-83. https://doi.org/10.1002/psp.481

Florida, R. (2002). Bohemia and economic geography. $J$ Econ Geogr, 2(1), 55-71. https://doi.org/10.1093/jeg/2.1.55

Geist, C., \& McManus, P. A. (2012). Different Reasons, Different Results: Implications of Migration by Gender and Family Status [Article]. Demography, 49(1), 197-217. https://doi.org/10.1007/s13524-011-0074-8

Gorman-Murray, A., Brennan-Horley, C., McLean, K., Waitt, G., \& Gibson, C. (2010). Mapping same-sex couple family households in Australia [Article]. Journal of Maps, 382-392. https://doi.org/10.4113/jom.2010.1094

Graves, P. E., \& Linneman, P. D. (1979). Household migration: Theoretical and empirical results. Journal of Urban Economics, 6(3), 383-404. http://www.sciencedirect.com/science/article/pii/009411907990038X

Green, A. E. (1997). A question of compromise? Case study evidence on the location and mobility 
strategies of dual career households [Article]. Regional Studies, 31(7), 641-657. https://doi.org/10.1080/00343409750130731

Greenwood, M. J. (1997). Chapter 12 Internal migration in developed countries. In Handbook of Population and Family Economics (Vol. 1, pp. 647-720). Elsevier. https://doi.org/https://doi.org/10.1016/S1574-003X(97)80004-9

Greenwood, M. J. (2005). Modeling migration. Encyclopedia of social measurement, 2, 725-734.

Halfacree, K. H., Flowerdew, R., \& Johnson, J. H. (1992). The Characteristics of British Migrants in the 1990s: Evidence from a New Survey. The Geographical Journal, 158(2), 157-169. http://www.jstor.org/stable/3059785

Hammar, T., Brochmann, G., Tamas, K., \& Faist, T. (2021). International migration, immobility and development: Multidisciplinary perspectives. Routledge.

Hardill, I., Green, A., Owen, D., \& Dudleston, A. (1997). Who Decides What? Decision Making in Dual-Career Households. Work, Employment \& Society, 11(2), 313-326. http://www.jstor.org/stable/23746127

Hoover, E. (1971). An Introduction to Regional Economics. Alfred A. Knopf.

Irwin, M., Blanchard, T., Tolbert, C., Nucci, A., \& Lyson, T. (2004). Why People Stay: The Impact of Community Context on Nonmigration in the USA. Population (English Edition, 2002-), 59(5), 567-591. http://www.jstor.org/stable/3654918

Jackman, R., \& Savouri, S. (1992). Regional Migration in Britain: An Analysis of Gross Flows Using NHS Central Register Data. The Economic Journal, 102(415), 1433-1450. http://www.jstor.org/stable/2234799

King, R. (2018). Context-Based Qualitative Research and Multi-sited Migration Studies in Europe. In R. Zapata-Barrero \& E. Yalaz (Eds.), Qualitative Research in European Migration Studies (pp. 35-56). Springer International Publishing. https://doi.org/10.1007/978-3-319-76861-8_3

Kolk, M., \& Andersson, G. (2020). Two decades of same-sex marriage in Sweden: A demographic account of developments in marriage, childbearing, and divorce. Demography, 57(1), 147-169.

Kopnina-Geyer, H. (1998). [International Migration, Immobility and Development: Multidisciplinary perspectives, T. Hammer, G. Brochman, K. Tamas, T. Faist]. Cambridge Anthropology, 20(3), 100-103. http://www.jstor.org/stable/23818819

Kulu, H. (2008). Fertility and spatial mobility in the life course: evidence from Austria. Environment and Planning A, 40(3), 632-652. http://www.envplan.com/abstract.cgi?id=a3914

Kulu, H., \& Milewski, N. (2007). Family change and migration in the life course: An introduction [Editorial Material]. Demographic Research, 17, 567-590. https://doi.org/19

Lee, E. S. (1966). A Theory of Migration. Demography, 3(1), 47-57. http://www.jstor.org/stable/2060063

Long, L. (1992). Changing Residence - Comparative Perspectives on its Relationship to Age, Sex and Marital-Status [Article]. Population Studies-a Journal of Demography, 46(1), 141-158. <Go to ISI $>$ ://A1992HG97300010

Long, L. H. (1972). The Influence of Number and Ages of Children on Residential Mobility. Demography, 9(3), 371-382. http://www.jstor.org/stable/2060860

Long, L. H. (1973). Migration Differentials by Education and Occupation: Trends and Variations. Demography, 10(2), 243-258. http://www.jstor.org/stable/2060816

Mangalam, J. (1968). Human migration: a guide to migration literature in English, 1955-1962.

Massey, D. S., Arango, J., Hugo, G., Kouaouci, A., Pellegrino, A., \& Taylor, J. E. (1993). Theories of International Migration: A Review and Appraisal. Population and Development Review, 19(3), 431-466. https://doi.org/10.2307/2938462

McHugh, K. E., Hogan, T. D., \& Happel, S. K. (1995). Multiple Residence and Cyclical Migration: A Life Course Perspective*. The Professional Geographer, 47(3), 251-267.

Miller, S. J. (1976). Family Life Cycle, Extended Family Orientations, and Economic Aspirations as Factors in the Propensity to Migrate. The Sociological Quarterly, 17(3), 323-335. http://www.jstor.org/stable/4105954

Mincer, J. (1978). Family Migration Decisions. The Journal of Political Economy, 86(5), 749-773. 
http://www.jstor.org/stable/1828408

Morrison, P. S., \& Clark, W. A. V. (2011). Internal migration and employment: macro flows and micro motives [Article]. Environment and Planning A, 43(8), 1948-1964. https://doi.org/10.1068/a43531

Mulder, C. H., \& Wagner, M. (1993). Migration and Marriage in the Life Course- A Method for Studying Synchronized Events. European Journal of Population-Revue Europeenne De Demographie, 9(1), 55-76. $\leq$ Go to ISI $>$ ://WOS:A1993MP73900003

Myers, S. M. (2000). The impact of religious involvement on migration. Social Forces, 79(2), 755-783.

Newbold, K. B., \& Bell, M. (2001). Return and Onwards Migration in Canada and Australia: Evidence From Fixed Interval Data. International Migration Review, 35(4), 1157-1184. https://doi.org/10.1111/j.1747-7379.2001.tb00056.x

Niebuhr, A. (2010). Migration and innovation: Does cultural diversity matter for regional R\&D activity? Papers in Regional Science, 89(3), 563-585.

Niedomysl, T. (2008). Residential preferences for interregional migration in Sweden: demographic, socioeconomic, and geographical determinants. Environment and Planning A, 40(5), 1109-1131. http://www.envplan.com/abstract.cgi?id=a39177

Niedomysl, T., \& Fransson, U. (2014). On Distance and the Spatial Dimension in the Definition of Internal Migration. Annals of the Association of American Geographers, 104(2), 357-372. https://doi.org/10.1080/00045608.2013.875809

Nivalainen, S. (2004). Determinants of family migration: short moves vs. long moves. Journal of Population Economics, 17(1), 157-175. https://doi.org/10.1007/s00148-003-0131-8

Pekkala, S. (2003). Migration Flows in Finland: Regional Differences in Migration Determinants and Migrant Types. International Regional Science Review, 26(4), 466-482. https://doi.org/10.1177/0160017603259861

Pekkala, S., \& Tervo, H. (2002). Unemployment and Migration: Does Moving Help? The Scandinavian Journal of Economics, 104(4), 621-639. http://www.jstor.org/stable/3440985

Pissarides, C. A., \& Wadsworth, J. (1989). Unemployment and the Inter-Regional Mobility of Labour. The Economic Journal, 99(397), 739-755. http://www.jstor.org/stable/2233768

Rhoades, S. A. (1993). The herfindahl-hirschman index. Fed. Res. Bull., 79, 188.

Ritchey, P. N. (1976). Explanations of Migration. Annual Review of Sociology, 2(1), 363-404. https://doi.org/doi:10.1146/annurev.so.02.080176.002051

Ritsilä, J., \& Ovaskainen, M. (2001). Migration and regional centralization of human capital. Applied Economics, 33(3), 317-325. https://doi.org/10.1080/00036840122485

Roseman, C. C. (1971). Migration as a Spatial and Temporal Process Annals of the Association of American Geographers, 61(3), 589-598. https://doi.org/10.1111/j.1467-8306.1971.tb00809.x

Sandefur, G. D., \& Scott, W. J. (1981). A Dynamic Analysis of Migration: An Assessment of the Effects of Age, Family and Career Variables. Demography, 18(3), 355-368. http://www.jstor.org/stable/2061003

Sandell, S. H. (1977). Women and the Economics of Family Migration. The Review of Economics and Statistics, 59(4), 406-414. https://doi.org/10.2307/1928705

Sargent, M., \& Holmes, K. (2014). An empirical analysis of the use of the Herfindahl-Hirschman Index in assessing the distribution of electronic gaming machines and its socio-economic implications. International Gambling Studies, 14(2), 251-265. https://doi.org/10.1080/14459795.2014.906639

Sassler, S., \& Lichter, D. T. (2020). Cohabitation and Marriage: Complexity and Diversity in Union-Formation Patterns. Journal of Marriage and Family, 82(1), 35-61. https://doi.org/https://doi.org/10.1111/jomf.12617

Sjaastad, L. A. (1962). The Costs and Returns of Human Migration. Journal of Political Economy, 70(5), 80-93. http://www.jstor.org/stable/1829105

Skeldon, R. (2012). 11 Migration and its measurement: towards a more robust map of bilateral flows. Handbook of Research Methods in Migration, 229.

Smith, D. P. (2004). An 'untied' research agenda for family migration: loosening the 'shackles' of the 
past. Journal of Ethnic and Migration Studies, 30(2), 263-282.

https://doi.org/10.1080/1369183042000200696

Smith, D. P. (2011). Geographies of long-distance family migration: Moving to a 'spatial turn'. Progress in Human Geography, 35(5), 652-668. https://doi.org/http://dx.doi.org/10.1177/0309132510394011

Smits, J. (2001). Career Migration, Self-selection and the Earnings of Married Men and Women in the Netherlands, 1981-93. Urban Studies, 38(3), 541-562. https://doi.org/10.1080/00420980120080091

Taylor, R. C. (1969). Migration and motivation: a study of determinants and types.

Trovato, F., \& Halli, S. S. (1983). Ethnicity and Migration in Canada. International Migration Review, 17(2), 245-267. http://www.jstor.org/stable/2545977

Vijverberg, W. P. M. (1993). Labour Market Performance as a Determinant of Migration. Economica, 60(238), 143-160. http://www.jstor.org/stable/2554586 (New Series)

Waite, L. J. (2005). Marriage and Family. In D. L. Poston \& M. Micklin (Eds.), Handbook of Population (pp. 87-108). Springer US. https://doi.org/10.1007/0-387-23106-4_4

Waitt, G., \& Gorman-Murray, A. (2011). Journeys and Returns: Home, Life Narratives and Remapping Sexuality in a Regional City [Article]. International Journal of Urban and Regional Research, 35(6), 1239-1255. https://doi.org/10.1111/j.1468-2427.2010.01006.x

White, M. J., \& Lindstrom, D. P. (2005). Internal migration. In Handbook of population (pp. 311-346). Springer. 